
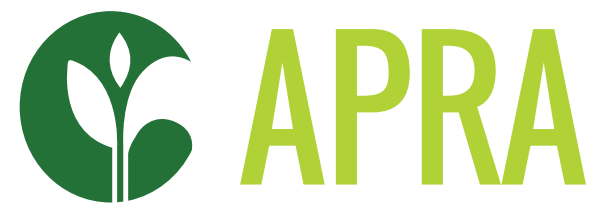

Agricultural Policy Research in Africa

\title{
THE ROLE OF SMALL-SCALE PROCESSORS IN SUPPORTING AGRICULTURAL COMMERCIALISATION AMONG SMALLHOLDER RICE FARMERS IN EAST AFRICA: LESSONS FROM ETHIOPIA AND TANZANIA
}

Dawit Alemu, Aida Isinika, Hannington Odame and John Thompson 


\section{CONTENTS}

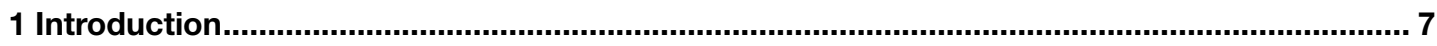

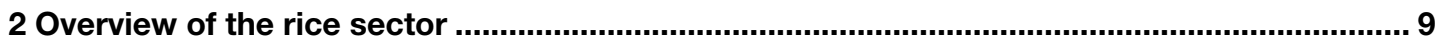

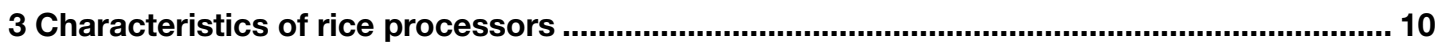

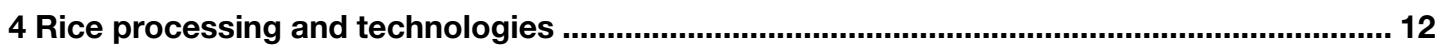

5 Commercial behaviour of rice processors............................................................................ 13

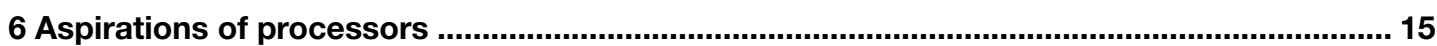

7 Role of processors in smallholders' rice commercialisation .................................................. 17

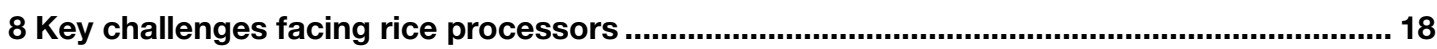

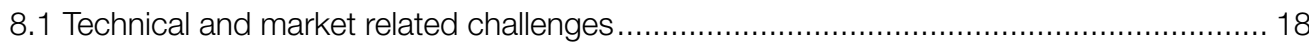

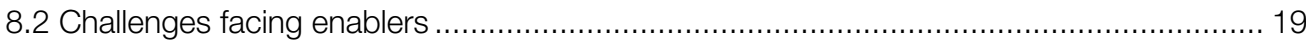

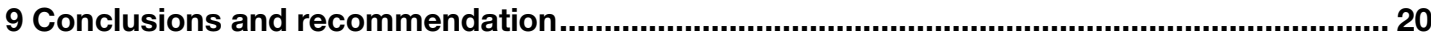

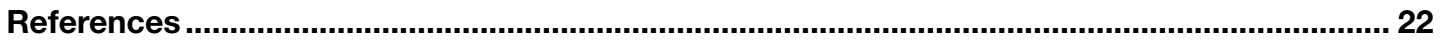

\section{List of tables}

Table 3.1 Socio-demographic characteristics of rice processors ....................................... 10

Table 3.2 Agriculture related resources owned by rice processors ....................................... 10

Table 3.3 Source of finance and estimated initial financing ............................................... 11

Table 3.4 Employment opportunities created by rice processors......................................... 11

Table 4.1 Type of processing machines owned by rice processors.................................. 12

Table 5.1 Rice processors' strategy for rice milling services and paddy sourcing.................. 13

Table 6.1 Aspirations and plans of rice processors.......................................................... 15

Table 8.1 Challenges faced by rice processors ……................................................... 18 


\section{DISCLAIMER}

We thank the local leaders and people of the Wereta City and the Fogera Plain region, Debub Gondar Zone, Amhara Region, Ethiopia, and the Kilombero District of Morogoro Region, Tanzania, particularly the rice processors and their employees, for their support in providing responses to our questions, showing us their milling facilities, and detailing the changes in their processing operations.

Dawit Alemu is Manager of the Bilateral Ethiopian-Netherlands Effort for Food, Income and Trade Partnership in Ethiopia. He is also a member of the Future Agricultures Consortium (FAC) and Country Lead of the Agricultural Policy Research in Africa (APRA) programme in Ethiopia. Aida Isinika is a Professor Emeritus at the Institute of Continuing Education at Sokoine University of Agriculture (SUA), Tanzania. An agricultural economist, she is a member of FAC and Country Lead for APRA in Tanzania. Hannington Odame is the Founder and Executive Director of Centre for African Bio-Entrepreneurship (CABE). A specialist in agricultural science, technology and innovation, he acts as Regional Coordinator for FAC and APRA in Eastern Africa. John Thompson is a resource geographer and Senior Research Fellow at the Institute of Development Studies (IDS), UK. He serves as the Director of FAC and CEO of APRA.

This working paper is funded with UK aid from the UK government (Foreign, Commonwealth \& Development Office - FCDO, formerly DFID). The opinions are the authors and do not necessarily reflect the views or policies of IDS or the UK government. 


\section{ACRONYMS}

APRA

CARD

FAC

FGD

IRRI

MFL

NRDS

SSA
Agricultural Policy Research for Africa

Coalition for African Rice Development

Future Agricultures Consortium

focus group discussion

International Rice Research Institute

Mamboleo Farm Limited

National Rice Development Strategy

sub-Saharan Africa 
Until recently, attention to rice value chain upgrading has been limited in many rice-producing countries of Eastern Africa. Yet, it is this mid-stream section (the millers and traders) - the so-called 'hidden middle' which is essential to sustaining the capacity of rice value chains to contributing to food security in the region, as it fulfils a crucial intermediary role between supply and demand.

In this paper, we focus on the role of rice processors as key actors in rice sector development in East Africa along with what challenges and opportunities they face, drawing on primary data generated from surveys and key informant interviews in Ethiopia and Tanzania. Specifically, we analyse results from two surveys of rice processors conducted by researchers in the Agricultural Policy Research in Africa (APRA) Programme of the Future Agricultures Consortium (FAC) in 2018. Data in Ethiopia was drawn from a census of 123 rice processors in Wereta City and the Fogera Plain area in the South Gondar Zone of Amhara Region, the major rice producing area in the country. In Tanzania, a random sample of 32 processors in Kilombero District of Morogoro Region was used.

We analyse rice processors in terms of their sociodemographic characteristics, ownership and use of processing technologies, commercial behaviour and interactions with rice producers, their rice marketing (both paddy and milled rice) practices, and their aspirations. We also assess the main challenges and opportunities facing rice processors in establishing and growing their operations.

Socio-demographic characteristics: Rice processors in Tanzania were more resource endowed compared to those in Ethiopia, mainly in terms of land and tractor ownership. The average size of land owned in Ethiopia is 1.5ha, with a range of 0.25-4.0ha, while in Tanzania, processors owned an average of 12ha, with a range of 0.81-82ha. In addition, a higher proportion of the rice processors in Tanzania (28 per cent) own their own tractors compared to those in Ethiopia (2.4 per cent).

Ownership and use of processing technologies: The survey results indicate a difference in the type of processing technology used between the two countries. The majority of the processors (84.3 per cent) in Ethiopia own one-pass/polishing machine, followed by those owning a dehusking machine (38.5 per cent). In Tanzania, about 56 per cent of the processors own two-pass machines, followed by one-pass/polishing machine (22 per cent). All types of machines are imported from China and operate either on diesel or electric power with different milling capacities. But their level of efficiency is lower than the best available in the market due to the limited capacity of processors to afford higher-quality machines

\section{Commercial behaviours of rice processors:}

The survey results indicate that rice processors engagement as milling service providers is very limited as none of the processors in Tanzania, and only 13.7 per cent of the processors in Ethiopia are not engaged in sourcing rice paddy - they only provide rice milling and storage services. Rice processors have limited incentives in only providing milling services as much higher benefits are gained through the procurement of paddy and the sale of milled rice, and from the byproduct market (broken rice and husks). In terms of paddy-sourcing strategies, rice processors normally negotiate unit price either for paddy or milled rice. If the processer purchases paddy rice, then the whole milling service and by-products will belong to them. However, rice processors prefer to negotiate the unit price for the milled rice for two major reasons. The first reason is to shift the risk of paddy quality to the producers as the quality of paddy rice, especially in terms of seed size uniformity, is often low, which affects the quality and quantity of milled rice. The second reason is it gives the opportunity to maximise benefits from the by-products (broken rice and husks) that are sold later by the processor.

Processors' aspirations: Survey results indicate that 88.5 per cent of processors in Ethiopia and 81.3 per cent in Tanzania would like to expand their rice processing business through diverse mechanisms. On the other hand, about 59 per cent of processors in Ethiopia and about 41 per cent in Tanzania have plans to expand their business into non-rice related businesses, including hoteling, construction, transport service provision, and also, processing of other agricultural commodities. 
Key challenges: The survey results indicate that processors face diverse challenges with considerable differences between the two countries in terms of their importance:

- Paddy supply: The main challenges were poor quality, shortage of supply, and the need to ensure timely aggregations;

- Processing technology: About 52 per cent of the processors in Ethiopia and about 34 per cent in Tanzania reported that the processing machines owned are old models with limited efficiency. About 63 per cent of the processors in Ethiopia and about 19 per cent in Tanzania reported that modern machines are not available in the local and domestic markets;

- Technology transfer: We found that there is no strong public service to ensure better transfer and access to technology along with technology management skills, which has resulted in the prevalence of a traditional processing approach. Donor-supported initiatives to ensure the transfer of rice-processing technologies are limited in coverage;

- Licensing of processors and standards: The assessment indicated that there is no standard or uniformity in the facilities and space available among rice processors in both countries, limiting investment for the processing facilities;

- Access to resources and services: Processors in both countries reported limitations related to access to land, finance, skilled labour and electric power as key challenges to sustain and expand their rice processing business, and;

- $\quad$ Rice markets: The challenges were related to (i) the competition of imported rice, (ii) inadequate local demand for milled rice, (iii) limited price incentives to produce quality paddy and milled rice, and (iv) lack of market information.

Accordingly, there is a need to (i) modernise and build the capacity of rice processors to ensure the competitiveness of domestic rice with imported rice, (ii) to standardise the key requirements for licensing a rice processing facility, and incentivise processors for the different scales of operation to fulfil quality standard requirements - which would require them to invest in key facilities, (iii) proactive public support in enhancing the transfer and adaption of rice technologies and their management practices, especially the postharvest management technologies from countries with experience in rice processing (such as Asia), and (iv) modernise the current rice marketing system that can provide adequate incentive for quality paddy rice production by farmers and quality milled rice production by processors. 
In sub-Saharan Africa (SSA), rice has become one of the strategic commodities for food security over the past decade. Development of the rice sector has focused on supply-side issues and investments, mainly related to improving production and productivity through the introduction of Green Revolution technologies and practices, such as modern seed varieties and fertilisation (Otsuka and Kalirajan, 2006; Ut and Kajisa, 2006; Roy-Macauley, 2019). More recently, attention has turned to adding value to domestically produced rice in national and regional value chains through the promotion of vertical linkages and networking among various independent business organisations engaged in its production, primary and secondary processing, packaging, storage, transport and distribution (Kaplinsky and Morris, 2000; Schmitz, 2005). In this regard, small-scale independent processors play a particularly crucial role in the transformation of these rice value chains.

Rice processing is not only about milling rice, but it is also about carrying out many other essential functions such as procurement, drying, storage and utilisation of by-products (Sekhon et al., 2003). In general, the major objective of milling paddy rice is to get maximum output of better-quality rice, with minimum breakage and without damaging usable by-products.

Following the food price crisis of 2007-2008, when the export price of rice exceeded US $\$ 1,000 / t$ (Pandey et al., 2010), governments in SSA recognised that rice sector development was crucial for national and regional food security. To close the gap between supply and demand, the Coalition for African Rice Development (CARD) was established in 2008 to promote rice sector development in 23 countries, with the support of the Government of Japan and various bilateral and multilateral agencies, and with technical assistance from the Consultative Group of International Agricultural Research (particularly AfricaRice and the International Rice Research Institute (IRRI)). Working in partnership with rice producing countries, CARD set a goal of doubling rice production (from 14 million t/year to 28 million t/year) over a 10-year period (2009-2019) (Ismail, 2019).

To achieve this ambitious target, CARD supported the development of National Rice Development Strategies
(NRDS) in each participating country. The formulation of the NRDS was led by the Ministries of Agriculture and other national institutions, and subjected to a broad policy-based dialogue and consultation with the active participation of relevant stakeholders in the rice value chain. Each NRDS assessed the entire rice sector in the country and focused on both 'supply-push' and 'demand-pull' actions, over the short, medium and long-term. However, more emphasis was placed on supply-side investments and improvements (Demont and Neven, 2013).

An analysis of CARD's achievements found that its contribution to paddy rice production in 2018 was 10.2 million t, equivalent to 74 per cent of its target. This contribution resulted from increases in area and yield of 23 per cent and 19 per cent, respectively. However, the study concluded that yield growth rate was not sustainable in almost two-thirds of the CARD countries because 'supply-push' factors, such as the promotion of new rice varieties, fertilisers and irrigation, were seen to have limited long-term effects on rice production (Arouna et al., 2021). Sustainable investments in 'demand-pull' factors involving value chain upgrading, such as improvements in the privately led modern milling sector, were less prominent in the NRDS. Nevertheless, the results showed that the contribution of CARD is significantly determined by these demand-pull factors through investments in value chain upgrading. The higher the investments in value chain upgrading, the higher the impact of the CARD policy. This finding suggests that investments in value chain upgrading through modern mill development and vertical coordination and integration can stimulate increases in rice paddy production. In turn, modern mills require high quantities of paddy rice to reach profitability and to recover the investments (Arouna et al., 2021).

In 2019, CARD launched a second phase with the aim to double rice production in SSA from 28 million MT in 2019 to 56 million MT by 2030 (CARD, 2019). To achieve this goal, CARD aims to continue to support the Ministry of Agriculture in each participating country to produce a new NRDS, with a greater focus on value chain upgrading, capacity strengthening and strong partnerships with the private sector (CARD, 2019). 
Despite this commitment, attention to rice value chain upgrading has been limited in many rice producing countries, with a few notable exceptions (e.g., Senegal and Nigeria in West Africa) during the first phase of CARD (Soullier et al., 2020). Yet, it is this mid-stream section (millers and traders) - the so-called 'hidden middle' - that is essential in sustaining rice value chains' capacity of providing food security in the region, as this fulfils a crucial intermediary role between supply and demand (Arouna, 2019; Arouna et al., 2020; Soullier and Moustier, 2020).

Consideration of the key factors by actors of the rice value chain to ensure the supply of quality rice from domestic production has been limited. Major factors for rice quality are related to: (i) pre-harvest cultivation practices, such as varietal uniformity and quality seed planted, time and amount of fertiliser application, time of harvesting, disease and pest management, (ii) harvesting and threshing, (iii) milling practices, (iv) storage conditions, (v) parboiling methods, and (vi) market incentives for quality rice processing (Futakuchi, Manful and Sakurai, 2013; Assaye and Alemu, 2020; Soullier, et al., 2020). Similarly, branding and labelling increase visibility and trust in rice consumption and are an integral part of the value chain upgrading and innovation. The nature of milling equipment also greatly affects rice quality (Demont and Neven, 2013).

In this paper, we focus on the role of rice processors as key actors in rice sector development in East Africa, drawing on primary data generated from surveys and key informant interviews in Ethiopia and Tanzania. Specifically, we analyse results from two surveys of rice processors conducted by researchers in the Agricultural Policy Research in Africa (APRA) Programme of the Future Agricultures Consortium (FAC) in 2018. In Ethiopia, data was drawn from a census of 123 rice processors in Wereta City and the Fogera Plain in the Debub Gondar Zone of Amhara Region, the major rice producing area in the country, and in Tanzania, a random sample of 32 processors in Kilombero District of Morogoro Region. We analyse rice processors in terms of their socio-demographic characteristics, ownership and use of processing technologies, commercial behaviour and interactions with rice producers, as well as their rice marketing (both paddy and milled rice) practices. We also assess the main challenges facing rice processors in establishing and growing their operations. 


\section{OVERVIEW OF THE RICE SECTOR}

The importance of rice in Eastern Africa in terms of domestic production and consumption is increasing year on year. Paradoxically, there has been a decline in the level of national self-sufficiency due to consumer demand exceeding available supply of locally produced rice, a trend observed in other parts of Africa (Wilson and Lewis, 2015). Recent figures show that the rice selfsufficiency levels in East Africa range from about 15 per cent in Kenya to 89 per cent in Tanzania, requiring the gap to be filled by imports, mainly from rice producing countries in Asia (AfricaRice, 2018).

In Ethiopia, rice has become one of the three important commodities next to wheat and oil crops, mainly in relation to the effort to ensure self-sufficiency and reduce the burden it is creating on the meagre foreign reserve. The trend in rice imports grew from 22,500 million t in 2008 to 533,620 million t in 2019, which indicates the decline of the level of self-sufficiency from 76 per cent in 2008 to 26 per cent in 2019 and an increase in foreign currency payments of US\$12.07 million in 2008 to around US\$186.2 million in 2019 (Alemu and Thompson, 2020). As a recent introduction to the country, rice is mainly produced in niche areas;
Fogera Plain of Amhara Region in the North-western part of the country is the major production area, contributing about 70 per cent of national production.

In Tanzania, rice is the second most produced cereal crop, with 1,382,794 million t of production engaging $1,676,859$ operators. The most important producing regions include Tabora, which accounts for about 17 per cent of the area under production in the mainland, followed by Morogoro (15 per cent) and Shinyanga (14 per cent). In Zanzibar, the Kusini Pemba region accounts for 35 per cent of the total rice area on the island, followed by Kaskazini Pemba with 25 per cent. In terms of rice production for mainland Tanzania, the leading regions are Shinyanga, Tabora, Mwanza, Mbeya, Rukwa and Morogoro (URT, 2018).

Unlike many other crops, rice demands additional activities once harvested. These are associated with the need to remove husk and bran layers to bring the grain to a state that is suitable for human consumption. The role of rice processors/millers is therefore crucial, not only in creating a market for paddy rice produced by farmers, but also in marketing the milled rice to different actors, including traders and consumers. 
We characterise rice processors in the region in relation to the socio-demographics, resource ownership, use of hired labour, and access to finance. This assessment provides a clear picture about the processors' capacity and practices.

The majority of owners of rice processing facilities surveyed in this study in both countries are men, accounting for about 90 per cent, with a small proportion (just under 10 per cent) owned and operated by women. The average age of processors is about 40 years and about 44 years, with about six and nine years of formal education in Ethiopia and Tanzania, respectively. Most of the processors in both countries are married with an average household size of about six in Ethiopia and four members in Tanzania (Table 3.1).
Most of the rice processors interviewed in Tanzania (78 per cent) reported operating their own agricultural land, while only 25 per cent of the processors in Ethiopia did so. The average size of land owned in Ethiopia is 1.5ha, with a range of 0.25-4.0ha, while in Tanzania, processors owned an average of $12 \mathrm{ha}$, with a range of 0.81-82ha. About 30 per cent of the processors in both countries' own livestock. In terms of mechanisation, a higher proportion of the rice processors in Tanzania (28 per cent) own their own tractors compared to only 2.4 per cent in Ethiopia. This is linked to the size of farmland operated.

In terms of access to finance for the initial investment for establishment of the processing facility, the assessment indicates that most of the rice processors used their own finance, and the average initial investment in Ethiopia was about US\$13,000 and in Tanzania,

Table 3.1 Socio-demographic characteristics of rice processors

\begin{tabular}{|c|c|c|c|c|}
\hline Variable & Measurement & Indicator & Ethiopia & Tanzania \\
\hline \multirow[t]{2}{*}{ Sex } & \multirow[t]{2}{*}{$\%$ of processors } & Male & 91.0 & 90.6 \\
\hline & & Female & 9.0 & 9.4 \\
\hline \multirow[t]{4}{*}{ Marital status } & \multirow[t]{4}{*}{$\%$ of processors } & Single & 19.7 & 3.1 \\
\hline & & Married & 76.2 & 93.8 \\
\hline & & Divorced & 1.6 & - \\
\hline & & Widow & 2.5 & 6.3 \\
\hline Age & $\begin{array}{l}\text { Average age of the } \\
\text { processor (Std) }\end{array}$ & No of years & 40.24 (12.64) & $43.56(9.60)$ \\
\hline Education & $\begin{array}{l}\text { Average year of formal } \\
\text { education (Std) }\end{array}$ & No of years & $6.16(4.64)$ & $8.97(4.04)$ \\
\hline Family size & $\begin{array}{l}\text { Average number of } \\
\text { household members } \\
\text { (Std) }\end{array}$ & Total & $6.21(2.74)$ & $4.22(3.06)$ \\
\hline
\end{tabular}

Source: Authors' own, using APRA rice processors' surveys (2018)

Table 3.2 Agriculture-related resources owned by rice processors

\begin{tabular}{|l|l|l|l|}
\hline Resource ownership & Indicators & Ethiopia & Tanzania \\
\hline \multirow{2}{*}{ Agricultural land * } & \% of processors & 25.2 & 78.1 \\
\cline { 2 - 4 } & Mean in ha (std) & 1.50 & $12.13(17.52)$ \\
\cline { 2 - 4 } & Range (ha) & $0.25-4.0$ & $0.81-80.97$ \\
\hline Livestock & \% of processors & 30.9 & 30.1 \\
\hline Tractor ownership & \% of processors & 2.4 & 28.1 \\
\hline
\end{tabular}

Note: * the percentage includes the processor with 105ha of land, making the sample 31 processors, but the mean value is estimated considering the remaining 30 processors.

Source: Authors' own, using APRA rice processors' surveys (2018) 
Table 3.3 Source of finance and estimated initial financing

\begin{tabular}{|l|l|l|l|l|}
\hline \multirow{2}{*}{$\begin{array}{l}\text { Source of finance } \\
\text { \% of processors }\end{array}$} & \multicolumn{4}{|c|}{ Estimated average initial investment } \\
\cline { 2 - 5 } & \% of processors & $\begin{array}{l}\text { Average amount } \\
\text { (US\$) }\end{array}$ & \% of processors & $\begin{array}{l}\text { Average amount } \\
\text { (US\$) }\end{array}$ \\
\cline { 2 - 5 } & 93 & 13,100 & 83 & 9,922 \\
\hline Own finance & 8 & 13,081 & 14 & 9,053 \\
\hline Bank loan & 7 & 7,833 & - & - \\
\hline Microfinance & 1 & 4,360 & 3 & 5,263 \\
\hline Cooperative & 19 & 4,011 & - & - \\
\hline $\begin{array}{l}\text { Loan from relatives } \\
\text { and friends }\end{array}$ & 1 & 18,169 & - & - \\
\hline $\begin{array}{l}\text { Non-governmental } \\
\text { organisations }\end{array}$ & 1 & 16,155 & & 9,665 \\
\hline $\begin{array}{l}\text { Average investment/ } \\
\text { processor }\end{array}$ & & & & \\
\hline
\end{tabular}

Note: The US $\$$ exchange rate was based on a 10-year average where we consider 1 US $\$=27.52$ Ethiopian Birr, and 1 US $\$=T S h 1,900$

Source: Authors' own, using APRA rice processors' surveys (2018)

Table 3.4 Employment opportunities created by rice processors

\begin{tabular}{|c|c|c|c|c|c|c|c|}
\hline \multirow{2}{*}{ Country } & \multirow{2}{*}{$\begin{array}{l}\text { Type of } \\
\text { labour }\end{array}$} & \multicolumn{2}{|c|}{ Casual } & \multicolumn{2}{|c|}{ Permanent } & \multicolumn{2}{|c|}{ Total } \\
\hline & & Mean & Std & Mean & Std & Mean & Std \\
\hline \multirow{3}{*}{ Ethiopia } & Male & 5.59 & 8.58 & 4.20 & 3.22 & 9.80 & 9.99 \\
\hline & Female & 0.20 & 1.14 & 0.27 & 0.91 & 0.46 & 1.45 \\
\hline & Total & 5.79 & 8.69 & 4.47 & 3.50 & 10.26 & 10.28 \\
\hline \multirow{3}{*}{ Tanzania } & Male & 2.66 & 2.53 & 1.53 & 1.56 & 2.62 & 3.13 \\
\hline & Female & 8.17 & 6.43 & 4.67 & 6.35 & 7.88 & 8.82 \\
\hline & Total & 3.66 & 4.10 & 1.73 & 2.14 & 3.33 & 4.58 \\
\hline
\end{tabular}

Source: APRA rice processors' surveys (2018)

about US\$10,000. In Ethiopia, nearly one in five rice processors (19 per cent) obtained loans from relatives and friends and about 8 per cent used bank loans. In Tanzania, about 14 per cent of the processors secured bank loans to invest in their operations. In terms of access to finance from cooperatives, the figures were small in both cases: only about 3 per cent in Tanzania and only 1 per cent in Ethiopia. This indicates the limited service provided to rice processors by both formal commercial banks and cooperative societies.

Rice processors use both casual and permanent labour for different activities, including loading and unloading of paddy and milled rice, facility cleaning, guarding of the processing facility, machine operation, and for paddy collection in rural areas. The survey indicates that with considerable variability, a processor hires about six causal labourers and about five permanent workers in Ethiopia, and about four casual labourers and about two permanent workers in Tanzania (Table 3.4). This indicates that although processors create better job opportunities in Ethiopia, overall, rice processors in the region are more small-scale family businesses dependent on their own family labour. 
In general, rice processing entails removal of husk (dehusking or dehulling) and the milling of bran layers (to produce white rice) to make it suitable for human consumption. Cleaning and grading are also important activities to ensure quality. Thus, rice processing involves three major steps, which are (i) cleaning, an activity usually undertaken after harvesting to remove foreign objects, like stones and twigs, using a destoner, paddy grader and paddy cleaner (ii) dehusking or dehulling, a process to remove the husk from the clean paddy to produce brown rice, and (iii) milling, a stage to remove the bran layer of dehusked rice, turning brown rice into white rice (Atungulu and Pan, 2014). Along the whole process, different methods that require different technologies are applied. These are single-pass, twopass, and multiple-pass rice milling methods that have their own respective technologies.

The three methods of rice processing are applied in both Ethiopia and Tanzania, where the single-pass rice mill is a technology used for custom rice milling at the small-scale level. The two-stage mill separates the hulling and polishing processes, with the milling process achieved by first using rubber rollers to remove the husk, and secondly, using a friction whitener made of steel to polish the resulting brown colour. Multiple-pass rice milling, practiced in large commercial or industrial mills, combines a number of operations, with the resulting white rice typically being of higher quality and yield compared with that from one- or two-stage mills.

The survey indicates that the most important investment for rice processors is on rice processing machines and skilled manpower to operate the machines. There are different types of rice processing machines operated by processors. The survey results indicate that the majority of the processors (84.3 per cent) in Ethiopia own one- pass/polishing machine, followed by those owning a dehusking machine (38.5 per cent). In Tanzania, about 56 per cent of the processors own two-pass machines followed by 22 per cent who own a one-pass/polishing machines (Table 4.1). All types of machines are imported from China and operate either on diesel or electric power with different milling capacities. But their level of efficiency is lower than the best that are available in the market due to the limited capacity of processors to afford higher quality machines. According to the Kilimo Trust (2014) efficiency loss due to processing increases the price of locally produced rice in East Africa by up to 30 per cent, making it less competitive to imported rice.

Table 4.1 Type of processing machines owned by rice processors

\begin{tabular}{|l|l|l|l|l|}
\hline \multirow{2}{*}{$\begin{array}{l}\text { Category of } \\
\text { processing machine }\end{array}$} & \multicolumn{2}{|c|}{ Ethiopia } & \multicolumn{2}{c|}{ Tanzania } \\
\cline { 2 - 5 } & $\%$ of processors & Type of machine & $\%$ of processors & Type of machine \\
\hline Dehusking machine & 38.5 & $\mathrm{~N}-70, \mathrm{~N}-90, \mathrm{Nx}-110$ & 9.38 & \multirow{2}{*}{ SB 10} \\
\hline $\begin{array}{l}\text { One-pass/polishing } \\
\text { machine }\end{array}$ & 84.3 & $\mathrm{~N}-70, \mathrm{~N}-90, \mathrm{Nx}-110$ & 21.88 & SB 50 \\
\hline Two-pass machine & 9.1 & SB-30, SB-50 & 56.25 & Multi-level \\
\hline Three-pass machine & 4.1 & Multi-level & 15.63 & \\
\hline Parboiling machine & 1.7 & $\begin{array}{l}\text { Might use all types of } \\
\text { machine }\end{array}$ & - & \\
\hline
\end{tabular}

Source: Authors' own, using APRA rice processors' surveys (2018) 


\section{COMMERCIAL BEHAVIOUR OF RICE PROCESSORS}

The survey results indicate that rice processors engagement as milling service providers is very limited as none of the processors in Tanzania and only 13.7 per cent of the processors in Ethiopia are not engaged in sourcing of paddy on their own rather they only provide rice milling and storage services. This indicates that rice processors predominantly undertake milling for the paddy procured directly from rice producers or through collectors or traders, and/or produced on own rice farm (Table 5.1). Rice processors have limited incentive in only providing milling services as much higher benefits are gained through procurement of paddy and sale of milled rice, and from the by-product market (broken rice and husks).

Linked with the different paddy sourcing strategies, rice processors normally negotiate unit price either for paddy or milled rice (Table 5.1). If the processer purchases paddy rice, then the whole milling service and by-products will belong to them. However, rice processors prefer to negotiate the unit price for the milled rice for two major reasons. The first reason is to shift the risk of paddy quality to the producers as the quality of paddy rice especially in terms of seed size uniformity is often low, which affects the quality and quality of milled rice. The second reason is it gives the opportunity to maximise benefits from the byproducts (broken rice and husks) that are sold later by the processor.

In Ethiopia, if the unit price negotiation is based on milled rice, the milling service is free and is compensated by the by-products generated after milling (i.e., broken rice and husks), which then belong to the rice processor. This arrangement often creates a conflict of interest in providing quality milling services. This is because the poorer the processing, the less milled rice and more by-products there are for the processor. Estimates in Ethiopia indicate that the average milling recovery of milled rice from paddy rice is found to be about 66 per cent, with a range of 45 to 80 per cent. The proportion of processors with optimal milling recovery, i.e., 69 per cent and above, was only about 41 per cent.

In general, paddy rice is composed of roughly 20 per cent rice hull or husk, 11 per cent bran layers, and 69 per cent starchy endosperm, also referred to as the total milled rice (Poonam, 2014). The type of mill, the quality of paddy, post-harvest handling, the rice variety, and the miller's skill influence milling performance. Good quality paddy processed in a multi-stage rice mill can yield 65-70 per cent of white rice (milling recovery) and 50-60 per cent whole grain (head rice) (Rickman et al., 2013).

In Tanzania, a focus group discussion (FGD) with key informants, as well as observations by the research team, revealed that considerable proportion of the millers (about 50 per cent) also provide harvested paddy storage services to farmers and traders. About 81.3 per cent of the millers own storage facilities with capacities ranging from 3 to 750 million $t$, and a mean of 227 million t. The famers and traders have two options for milling: if they store and mill at the same location, they get the storage service for free or at a reduced rate. If they take their paddy out (often by selling it to a trader who will have the rice milled elsewhere), the storage fees will be higher. Only 5.6 per cent of the clients opted for cash storage fee payment.

Table 5.1 Rice processors' strategy for rice milling services and paddy sourcing

\begin{tabular}{|l|l|l|}
\hline & \multicolumn{2}{|c|}{$\%$ of rice processors } \\
\hline Paddy source & Ethiopia & Tanzania \\
\hline Own farm & 20.3 & 48.1 \\
\hline Rice producers & 61.8 & 25.9 \\
\hline Collectors & 18.7 & 11.1 \\
\hline Traders & 44.7 & 14.8 \\
\hline Only milling service & 13.8 & - \\
\hline
\end{tabular}

Note: percentages do not add to 100 due to multiple responses

Source: Authors' own, using APRA Rice processors' surveys (2018) 
Farmers and traders do not often collect the husks after milling. The miller allows women to come and winnow the husks to get broken rice for sale or domestic use. Some of the husks are collected by villagers which are burnt in the process of brickmaking. Some of the fine husk from rice polishing may be sold to animal feed processing plants. However, most of the husks are treated as waste and simply accumulated around the mill. Some of this is then burnt before the rains when it is still dry.

The FGDs indicate that the low recovery of milled rice is associated with two major factors. The first relates to the poor quality of paddy as a result of high moisture content and low uniformity in grain size (varietal mix). The second regards the financial incentive processors have as the low recovery (more broken rice) implies more gain for them.

The FGDs further indicated that the interest of rice processors to provide only milling and storage services is an attempt to monopolise the rice market - by limiting the competition of traders with the financial capacity to invest in paddy and milled rice services. The arrangement of milling service forces farmers to sell to processors rather than looking for other marketing options, including traders. 


\section{ASPIRATIONS OF PROCESSORS}

Processors were asked about their aspirations and future plans for their businesses. The results indicate that 88.5 per cent of processors in Ethiopia and 81.3 per cent in Tanzania would like to expand their rice processing business through diverse mechanisms, as shown in Table 6.1. Meanwhile, about 59 per cent of processors in Ethiopia and about 41 per cent in
Tanzania have plans to expand their businesses into non-rice related businesses including hoteling, construction, transport service provision, and also processing of other agricultural commodities.

Unlike other crops, rice has a spill-over effect on urbanisation - mainly linked with the processing industry which contributes to the emergence of diverse

Table 6.1 Aspirations and plans of rice processors

\begin{tabular}{|c|c|c|c|c|c|}
\hline \multirow{2}{*}{ Business type } & \multirow{2}{*}{ Type of business expansion } & \multicolumn{2}{|c|}{ Ethiopia } & \multicolumn{2}{|c|}{ Tanzania } \\
\hline & & \multicolumn{2}{|c|}{$\%$ of processors } & \multicolumn{2}{|c|}{$\%$ of processors } \\
\hline \multirow{7}{*}{$\begin{array}{l}\text { Plan to expand } \\
\text { rice business } \\
\text { (yes) }\end{array}$} & Purchase more processing machines & 74.0 & \multirow{7}{*}{88.5} & 37.5 & \multirow{7}{*}{81.3} \\
\hline & Import modern processing machine & 57.7 & & 34.4 & \\
\hline & Employ more labour & 69.9 & & 12.5 & \\
\hline & Engage in direct rice production & 19.5 & & 9.4 & \\
\hline & Establish new processing facility in the same town & 44.7 & & 43.8 & \\
\hline & Establish new processing facility in other towns & 32.5 & & & \\
\hline & $\begin{array}{l}\text { Utilise the full potential processing capacity of the } \\
\text { same machines }\end{array}$ & 74.0 & & 15.6 & \\
\hline \multirow{5}{*}{$\begin{array}{l}\text { Plan to expand } \\
\text { to non-rice } \\
\text { business (yes) }\end{array}$} & Hotel industry & 15.4 & \multirow{5}{*}{59.0} & 3.1 & \multirow{5}{*}{40.6} \\
\hline & $\begin{array}{l}\text { Building construction (town residence or business } \\
\text { house) }\end{array}$ & 22.0 & & 9.4 & \\
\hline & Transport sector & 30.1 & & 6.3 & \\
\hline & Trading of other products & 35.8 & & 9.4 & \\
\hline & Processing of other agricultural products & 27.6 & & 6.3 & \\
\hline
\end{tabular}

Source: Authors' own, using APRA rice processors' surveys (2018)

\section{Box 6.1 The 'white gold' of Wereta: A city raised on rice}

In the Fogera Plain in northern Ethiopia, rice is referred to as 'white gold' by local people to indicate the significant contribution it has made to enhancing agrarian change in rural areas, and in stimulating the emergence and modernisation of towns. It is estimated that, on average, 100,000 million $t$ of rice is brought into Wereta City every year to be processed and marketed (Tadesse, Alemu and Assaye, 2020). At the end of 2019, there were 119 rice processors operating in Wereta, who are creating local employment opportunities and providing valuable services. In addition, increased incomes for rice farmers and processors have created demand for goods and services; a number of business opportunities have emerged, including the expansion of hotels, wholesaling, retailing and banking. This has culminated in the recognition and change of the status of Wereta town to city status by the regional government. In this regard, the reported aspiration of rice processors is highly linked with the opportunities rice offers in enhancing local investments that are crucial for economic growth. 
business opportunities. In this regard, the commercial aspiration of rice processors and their expansion investments, both for rice processing and in non-rice sectors, have a role in steering economic development (Box 6.1). 


\section{ROLE OF PROGESSORS IN SMALLHOLDER RIGE COMMERCIALISATION}

Rice processors play a vital role not only in ensuring access to processing services, but also in serving as a point of paddy rice marketing for smallholder farmers. The mere need to get paddy rice processed, especially for domestic consumption, forces smallholder farmers to use rice processors as the dominant place of marketing. In the case of Ethiopia, data from rice producers indicates that 60 per cent sell directly to processors, 18 per cent to traders, 14.5 per cent to collectors, 5 per cent to brokers and the rest (about 3 per cent) to others buyers - mainly consumers. This indicates the important role of rice processors in enhancing market access.

The commercial behaviour of rice processors has a considerable influence on the commercial behaviour of smallholder rice farmers. The commercial behaviours of rice processors vary by country. In the case of Ethiopia, rice processors provide milling services for free, with an agreement whereby they buy the milled rice or the paddy rice and keep the by-product (husk and bran with a certain amount of broken rice). Rice processors normally negotiate a unit price for the paddy or milled rice depending on different sourcing strategies, which include: (i) direct purchase from rice producers (dominant strategy), (ii) purchase through collectors on behalf of a processor or a broker (delala), and (iii) purchase from a farmer-trader.

In the case of Tanzania, rice processors serve as both milling service providers, at an agreed fee, and as providers of marketing services for rice producers and traders. Most of the millers who own storage facilities around their plants use them as a means of securing the paddy to their plants. They incentivise rice traders and farmers to store their paddy in their facilities free of charge, on the condition that the stored paddy will only be processed at their plants. About 5.6 per cent of processors who own their own milling facilities charge storage costs to rice farmers, arguing that they have experienced cheating from some customers who collect their rice from their storage and take it to be milled by other processors.

The main rice by-products in Mngeta in Tanzania are not used as alternatives for the processing fees, they are always left on the plants and the millers either sell the material to livestock keepers as animal feed or to local brickmakers who use it as fuel to fire their kilns. Some of the large millers, such as Kilombero Plantation Limited when it was still operating, use the rice husks to generate electricity, and the Mamboleo Farm Limited (MFL) uses the husk as a soil amendment mulch. MFL was also part of a trial project (run by the Ministry of Agriculture Food Security and Cooperatives of Tanzania) that produced rice husk ash, which was then processed into briskets for fuel (Kilimo Trust, 2018). In Mbeya Region (Mbarali), another major rice producing area, the buyers of rice husks come from neighbouring regions. They use the husks as mulch for planting commercial avocado trees. 


\section{KEY CHALLENGES FACING RICE PROCESSORS}

The key challenges facing the rice processing sector can be categorised into two. The first category of challenges are linked with the processors themselves, and relate to the supply of paddy, processing technologies owned, availability of other required facilities, and rice market factors (Table 8.1). The second category of challenges mainly relate to enablers associated with general incentives and policy issues.

\subsection{Technical and market-related challenges}

Paddy supply: The challenges identified in the area of paddy supply are poor quality, shortage of supply, and the need to ensure timely aggregations. Rice is generally produced by small-scale farmers using diverse types of rice varieties and agronomic practices, resulting in different quality of paddy, mainly in terms of grain size and moisture content. In general, uniformity of grain size with appropriate moisture content are key requirements for improved milling recovery, and for producing goodquality milled rice (Poonam, 2014). In this regard, about 93 per cent of the rice processors in Ethiopia and about 28 per cent in Tanzania reported the poor quality of paddy supplied as a challenge. Shortages of paddy supply, in relation to the existing processing capacity, was reported by about 85 per cent of processors in Ethiopia and about 47 per cent of the processors in Tanzania. About 51 per cent of processors in Ethiopia and about 16 per cent in Tanzania reported aggregation as their main challenge.

Processing technology: About 52 per cent of the processors in Ethiopia and about 34 per cent in Tanzania reported that the processing machines they own are old models with limited efficiency. About 63 per cent of the processors in Ethiopia and about 19 per cent in Tanzania reported that modern machines are not available in the local and domestic markets.

Required resources and services: Processors reported limitations related with access to land, finance, skilled labour and electric power as key challenges to sustain and expand their rice processing businesses. For Ethiopian rice processors, limited access and interrupted supply of electricity (91 per cent) and limited access to required finance (73 per cent) were reported as the most important challenges, followed

Table 8.1 Challenges faced by rice processors (\% of processors)

\begin{tabular}{|c|c|c|c|}
\hline \multirow{2}{*}{ Category } & \multirow{2}{*}{ Challenges } & \multicolumn{2}{|c|}{$\%$ of processors } \\
\hline & & Ethiopia & Tanzania \\
\hline \multirow[t]{3}{*}{ 1) Paddy supply } & a) Supply of poor-quality paddy rice & 92.6 & 28.1 \\
\hline & b) Inadequate supply of paddy rice & 85.2 & 46.9 \\
\hline & c) Challenges related with aggregation from small producers & 50.8 & 15.6 \\
\hline \multirow{2}{*}{$\begin{array}{l}\text { 2) Processing } \\
\text { technology }\end{array}$} & a) Poor quality, old model or inefficient machines & 51.6 & 34.4 \\
\hline & b) Unavailability of quality and modern machines in the local market & 63.1 & 18.8 \\
\hline \multirow{5}{*}{$\begin{array}{l}\text { 3) Required } \\
\text { resources and } \\
\text { services }\end{array}$} & a) Lack of land to expand processing business & 59.0 & 18.8 \\
\hline & b) Lack of capital to expand processing business & 73.8 & 71.9 \\
\hline & c) Lack of land to establish other businesses & 54.1 & 9.4 \\
\hline & d) Lack of skilled labour for processing & 51.6 & 25.0 \\
\hline & e) Frequent interruption of electric power & 91.8 & 21.9 \\
\hline \multirow[t]{4}{*}{ 4) Rice markets } & a) Inadequate local demand on milled rice & 61.5 & 9.4 \\
\hline & b) Lack of price incentive for quality rice product & 59.0 & 9.4 \\
\hline & c) Lack of market information & 43.8 & 18.8 \\
\hline & d) Huge competition from imported rice & 71.9 & 31.3 \\
\hline
\end{tabular}

Source: Authors' own, using APRA rice processors' surveys (2018) 
by limited access to land for business expansion (59 per cent) and for establishment of other businesses (54 per cent). Lack of skilled labour to operate processing machines was also reported by 52 per cent of the processors. For rice processors in Tanzania, a lack of capital to expand processing businesses was reported by about 71 per cent of the processors; lack of skilled labour was reported by about 25 per cent; and frequent interruption of electric power was reported by 22 per cent of the processors to be the major challenges.

Rice markets: The challenges reported by processors in terms of rice marketing related to the competition of imported rice - as claimed by 72 per cent of the processors in Ethiopia and by about 31 per cent in Tanzania. Other challenges include inadequate local demand for milled rice, as reported by 62 per cent of the processors in Ethiopia and about 9 per cent in Tanzania (Table 8.1), limited price incentives to produce quality paddy and milled rice, as reported by 59 per cent of the processors in Ethiopia and about 9 per cent in Tanzania, and lack of market information, as reported by 44 per cent of the processors in Ethiopia and by about 19 per cent in Tanzania.

The figures clearly indicate the difference between the two countries in the importance of identified challenges, with a clear trend in severity - in terms of the proportion of rice processors - is higher in Ethiopia than Tanzania. This pattern can be associated with rice cultivation and processing traditions of the two countries; in Ethiopia, rice is a recent introduction to the country and the rice processing industry is still at its infant stage, compared to Tanzania, where there is a long history of rice cultivation and processing (MoAFS\&C, 2009; MoA, 2020).

\subsection{Challenges facing enablers}

The main policy-related challenges identified relate to technology transfer and standards for setting up rice processing business.

Given the global advancement of rice production and processing, both countries can capitalise on available technologies through proper introduction and adaption through diverse business models and public incentives. In this regard, the assessment indicates that there is no strong public service to ensure improved transfer and access to technologies, along with technology management skills, which has resulted in the prevalence of traditional processing approaches. Donor-supported initiatives to ensure the transfer of rice-processing technologies are limited in coverage.

Rice processing requires different facilities and space for cleaning and grading, milling, and storage. The assessment indicates that there is no standard or uniformity in the facilities and space available among rice processors. This is the result of the lack of national standards for setting up rice processing facilities, specifically in relation to space required, by-product management, required storage facilities etc. In this regard, local authorities engaged in allocating land and business licenses to allow rice processors to operate are not aware of what is required, which makes it difficult for them to facilitate the establishment of proper rice processing facilities. Thus, it will be important to set up standards for different rice processing scales of operation, which will guide the licensing and provision of required support from the public sector.

In summary, the identified challenges are very crucial if the rice sector, based on smallholder production systems, is to contribute to ensuring livelihood improvements for all rice actors and the respective country's vision to be self-sufficient in rice. In 2019, Ethiopia imported about 74 per cent of the total rice consumed, estimated at 533,620 million t of milled rice and costing the country US\$186.2 million (Alemu and Thompson, 2020). Tanzania is said to be nearly self-sufficient in rice (Kilimo Trust, 2014) but available information shows that supply falls short of demand (Isinika et al., 2020). It estimated than the country imports about 140,000 million t of rice (Kilimo Trust, 2014), which costs nearly US\$75 million (GAIN, 2018). Most of the imported rice is of low quality to substitute for higher-quality aromatic rice that is exported to neighbouring countries in the regional markets. Local demand is also high. About 30 per cent of the rice produced is consumed in producing areas. The remaining 70 per cent is mostly sold in the local market and less than 20 per cent is exported, mostly to neighbouring countries (URT, 2019). 
The development of a vibrant rice processing industry plays a crucial role in the expansion of rice production as a pull factor, along with enhancing the commercialisation of smallholder rice producers. However, the rice processing industry in both countries faces a number of challenges that need due attention if it is to contribute to the general problems of the agricultural sector, including ensuring food security and import substitution to save the meagre foreign currency reserves. In Ethiopia, rice is currently considered among the four priority crops for food security and agro industrial park development. Similarly, in Tanzania, programmes like the Rice Development Strategy aim at increasing competitiveness and improving the postharvest value chain of smallholder rice farmers in the major rice producing areas of Morogoro and Mbeya regions in the southern zone, and Shinyanga, Tabora and Mwanza regions in the Lake zone.

In general, rice processors in the two countries use older processing machines with limited ownership of other required facilities, including paddy and milled rice grading facilities, and adequate storage and transport facilities, which in turn, is affecting the quality of processing. Furthermore, most processors reported the underutilisation of available milling capacity, forcing them to diversify their engagement in the processing/ milling of other crops rather than specialising in rice processing and product development.

Looking into the multifaceted challenges facing processors, along with the existing opportunities, the following recommendations are offered:

- There is a need to modernise and build the capacity of rice processors to ensure the competitiveness of domestic rice. This demands professionalisation of the sector by providing formal training for the operation and maintenance of rice processing facilities. In recognition of this, both countries have a National Rice Research and Training Centre that has been established with support from the national governments and the Japanese International Cooperation Agency. However, the uptake of these training services by local processors is still minimal, which implies the need to provide due attention to data management to inform changes in policy and practice, to link productivity increase with market needs. Millers' associations can support their members to take advantage of these opportunities to improve their knowledge and skills and enhance their operations.

- There is no one-size-fits-all approach to rice value chain upgrading that will work in all contexts in Eastern Africa. Policy makers will need to find an optimal mix between encouraging productivity, demand and value chain upgrading to foster crowding in of private investment (both domestic and international), building on the specific priorities set out in their NRDS. Nevertheless, there is a need to standardise the key requirements for licensing rice processing facilities and incentivise processors for the different scales of operation (i.e., through the provision of land with a reduced lease, soft loans or tax holidays). This would encourage processors to meet quality standard requirements and invest in key facilities. The public sector could also facilitate business-tobusiness linkages and provide information about rice processing technologies and practices, including licencing establishing differentiated storage for paddy and milled rice, and grading and packaging. This calls for strengthening intersectoral linkages and coordination between Ministries of Agriculture, Trade and Industry, and Information and Communications Technology.

- Support is also needed to enhance the transfer and adaptation of rice milling technologies and related management practices, especially post-harvest management, from countries with experience in rice processing (such as Asia and some parts of West Africa). It will be important to provide a variety of processing equipment that can meet different size, quality and investment requirements. This can be facilitated by development partners from countries with advanced rice industries, and supported by the provision of accessible and affordable credit and finance for investment, including low-interest loans from agricultural banks and finance corporations. 
- Under the current rice marketing arrangements, there is no incentive for quality paddy rice production by farmers and quality milled rice production by processors. Again, if domestic rice is going to be competitive, there has to be a market incentive for quality for both paddy and milled rice production. Increased competitiveness of domestic rice relative to imported rice based on quality will require greater integration of domestic rice markets into global markets, with more elastic demand.

- The public sector needs to adapt and promote an improved paddy and milled rice marketing system, such as the Ethiopian commodity exchangetrading platform, to enhance linkages between producers and consumers. This could be coupled with a Warehousing Receipt System to improve storage, reduce post-harvest losses, stabilise market prices and facilitate access to formal credit and finance by rice millers and other actors in the value chain. 
Abdelbagi, I. (2019) 'Towards Rice Self-sufficiency in Africa', in: T. Tadesse, M. Atnaf, D. Alemu, T. Tadesse and K. Shiratori (eds), Advances in Rice Research and Development in Ethiopia. Addis Ababa: Ethiopian Institute of Agricultural Research.

AfricaRice (2018) Continental Investment Plan for Accelerating Rice Self-Sufficiency in Africa (CiPRiSSA), Abidjan: Africa Rice Center.

Alemu, D., Assaye, A., Addis, D., Tadesse, T., Tesfaye, A. and Thompson, J. (2018) A Historical Analysis of Rice Commericalisation in Ethiopia: The Case of the Fogera Plain. APRA Working Paper 18. Brighton: Future Agricultures Consortium. Available at: https://opendocs.ids.ac.uk/opendocs/handle/20.500.12413/16695 (Accessed: 14 September 2021).

Alemu, D. and Thompson, J. (2020) The Emerging Importance of Rice as a Strategic Crop in Ethiopia. APRA Working Paper 44. Brighton: Future Agricultures Consortium. Available at: https://opendocs.ids.ac.uk/opendocs/ handle/20.500.12413/15739 (Accessed: 02 November 2020.

Arouna, A. (2019) Leveraging Small and Medium Rice Millers for Rural Transformation and Investment in the Rice Sector in Africa. Workshop Report: 28-30 May 2019, Dar es Salam, Tanzania. Rome: FAO; Abidjan: AfricaRice. Available at: https://43c018b3-2e2d-4407-af86-1d6495506405.filesusr.com/ugd/0839e4_ c00512bec3784328b0d758fbe8edae1a.pdf (Accessed: 21 October 2021).

Arouna, A., Akoko Fatognon, I., Saito, K. and Futakuchi, K. (2021) 'Moving toward rice self-sufficiency in subSaharan Africa by 2030: Lessons learned from 10 years of the coalition for African rice development', World Development Perspectives 21 (March 2021) Available at: https://doi.org/10.1016/j.wdp.2021.100291 (Accessed: 25 February 2021).

Arounda, A., Soullier, G., Mendez del Villar, P. and Demont, M. (2020) 'Policy Options for Mitigating Impacts of COVID-19 on Domestic Rice Value Chains and Food Security in West Africa', Global Food Security 26 (September 2020), 100405. Available at: https://doi.org/10.1016/j.gfs.2020.100405 (Accessed: 22 October 2021).

Assaye, A. and Alemu, D. (2020) Enhancing Production of Quality Rice in Ethiopia: Dis/incentives for Rice Processors. APRA Policy Brief 22. Brighton: Future Agricultures Consortium. Available at: https://opendocs.ids. ac.uk/opendocs/handle/20.500.12413/16700 (Accessed: 4 May 2020).

Atungulu, G. and Pan, Z. (2014) 'Rice industrial processing worldwide and impact on macro- and micronutrient content, stability, and retention', New York Academy of Sciences, 15-28.

CARD (Coalition for African Rice Development). (2019) Coalition for African Rice Development, Phase 2. Nairobi: CARD. Available at: https://www.riceforafrica.net/images/card_photos/ticad7/pamphlet_en1.pdf (Accessed: 22 October 2021).

Demont, M. and Neven, D. (2013) 'Tailoring African Rice value chain to consumers', in: M.C.S. Wopereis, D.E. Johnson, N. Ahmadi, E. Tollens and A. Jalloh (eds.) 2013. Realising Africa's Rice Promise. Nairobi: CAB International.

Dhankhar, P. (2014) ‘Rice milling', IOSR Journal of Engineering (IOSRJEN), 04 (05): 34-42.

Futakuchi, K., Manful, J. and Sakurai, T. (2013) 'Improving grain quality of locally produced rice in Africa', in: M.C.S. Wopereis, D.E. Johnson, N. Ahmadi, E. Tollens and A. Jalloh (eds.) 2013. Realising Africa's Rice Promise. Nairobi: CAB International. 
GAIN (Global Agricultural Information Network). (2018) Tanzania Corn, Wheat and Rice 2018 Report. Available at: https://apps.fas.usda.gov/newgainapi/api/report/downloadreportbyfilename?filename=Grain\%20and\%20 Feed\%20Annual_Dar\%20es\%20Salaam_Tanzania\%20-\%20United\%20Republic\%20of_4-6-2018.pdf (Accessed: 20 September 2021).

Isinika, A., Mdoe, N., Mlay, G., Kilave, D., Magomba, C., Jeckoniah, J. and Boniface G. (2020) Rice Exports, an Untapped Potential in Tanzania: Factors Limiting Rice Commercialisation in Mngeta, Kilombero Valley. Paper presented at the AGREST Annual Workshop, 2-5 December 2020, Dodoma, Tanzania.

Ismail, Abdelbagi(2019). Towards Rice Self-sufficiency in Africa. Pp 24 - 31. In: Tadesse T., Atnaf M., Alemu D., Tadesse T, and Shiratori K. (eds). 2019. Advances in Rice Research and Development in Ethiopia. Ethiopian Institute of Agricultural Research. (EIAR)

Kaplinsky, R. and Morris. M. (2000) A Handbook for Value Chain Research. Ottawa: International Development Research Centre (IDRC).

Kilimo Trust. (2014) Expanding Rice Markets in the EAC. Kampala: Kilimo Trust. Available at: https://www. kilimotrust.org/documents/RICE\%20REPORt.pdf (Accessed: 8 August 2021).

MoA (Ministry of Agriculture). (2020) National Rice Development Strategy-II (2020 - 2030). Addis Ababa: Ministry of Agriculture. Available at: https://riceforafrica.net/images/countries/NRDS_rev/ethiopia_nrds2.pdf (Accessed: 22 October 2021).

MoA (Ministry of Agriculture). (2015) Agriculture Sector Growth and Transformation Plan II (2015-2020). Addis Ababa: Ministry of Agriculture.

MoAFS\&C (Ministry of Agriculture Food Security and Cooperatives). (2009). National Rice Development Strategy (2009 - 2019). Dar es Salaam: MoAFS\&C. Available at: https://riceforafrica.net/downloads/NRDS/tanzania_en.pdf (Accessed: 22 October 2021).

OECD (Organisation for Economic Co-operation and Development) and FAO (Food and Agriculture Organization of the United Nations). (2019) OECD-FAO Agricultural Outlook 2019-2028. Paris: OECD; Rome: FAO. Available at: https://doi.org/10.1787/agr_outlook-2019-en (Accessed: 25 June 2021).

Otsuka, K. and Kalirajan, K.P. (2006) 'Rice green revolution in Asia and its transferability to Africa: An introduction', The Developing Economies, XLIV-2: 107-22.

Poonam D. (2014). ‘Rice milling', IOSR Journal of Engineering 4(5): 2278-8719.

Rickman, J., Moreira, J., Gummert, M. and Woperies. M.C.S. (2013) 'Mechanising Africa's Rice Sector', in: M.C.S. Wopereis, D.E. Johnson, N. Ahmadi, E. Tollens and A. Jalloh (eds.), Realising Africa's Rice Promise. Nairobi: CAB International.

Roy-Macauley, H. (2019) 'Rice Research for Development in Africa: Experience from AfricaRice', in: T. Tadesse, M. Atnaf, D. Alemu, T. Tadesse and K. Shiratori (eds.), Advances in Rice Research and Development in Ethiopia. Addis Ababa: Ethiopian Institute of Agricultural Research (EIAR).

Schmitz, H. (2005) Value Chain Analysis for Policymakers and Practitioners. Geneva: International Labour Organisation.

Sekhon, M.K., Rangi, P.S. and Kaur, M. (2003) 'Rice Processing Industry in Punjab: Problems and Their Remedies', Indian Journal of Agricultural Economics 58(3): 544-553.

Soullier, G., Demont, M., Arounad, A., Lançona, F. and Mendez del Villare, P. (2020) 'The state of rice value chain upgrading in West Africa', Global Food Security 25: 100365.

Soullier, G. and Moustier. P. (2020) 'The modernization of the rice value chain in Senegal: A move toward the Asian quiet revolution?', Development Policy Review 12459.

Tadesse, T., Alemu, D. and Assaye, A. (2020) The White Gold of Wereta: A City Raised on Rice. APRA Policy Brief 24. Brighton: Future Agricultures Consortium. Available at: https://opendocs.ids.ac.uk/opendocs/ handle/20.500.12413/16702 (Accessed: 30 April 2020). 
Trevor, W.R. and Lewis, I. (2015) The Rice Value Chain in Tanzania. A Report from the Southern Highlands Food Systems Programme. Rome: Food and Agriculture Organization of the United Nations.

URT (United Republic of Tanzania). (2018) 2016/17 Annual Agriculture Sample Survey. National Bureau of Statistics. Dar es Salaam: URT.

URT (United Republic of Tanzania). (2019) National Rice Development Strategy 2019-2030 (NRDS II) (July 2019). Dar es Salaam: URT. Available at: https://riceforafrica.net/images/countries/NRDS_rev/NRDS2_Tanzania_en.pdf (Accessed: 22 October 2021).

USDA (United States Department of Agriculture). (2018) Grain and Feed Annual: 2018 West Africa Rice Annual (Gain Report). Washington, DC: Global Agriculture Information Network, USDA.

Ut, T.T. and Kajisa, K. (2006) 'The impact of the green revolution on rice production in Vietnam', The Developing Economies, XLIV-2: 167-89.

Wilson, R.T. and Lewis, I. (2015) The Rice Value Chain in Tanzania. A Report from the Southern Highlands Food Systems Programme. Rome: Food and Agriculture Organization of the United Nations (FAO). 
Alemu, D., Isinika, A., Odame, H. and Thompson, J. (2021) The Role of Small-Scale Processors in Supporting Agricultural Commercialisation Among Smallholder Rice Farmers in East Africa: Lessons from Ethiopia and Tanzania, APRA Working Paper 74, Brighton: Future Agricultures Consortium

(c) APRA 2021

ISBN: 978-1-78118-879-8

DOI: $10.19088 /$ APRA.2021.040

\section{(cc) BY-NC-ND}

This is an Open Access report distributed under the terms of the Attribution-Non Commercial-No Derivs 4.0 Unported (CC BY-NC-ND 4.0) Attribution - You must give appropriate credit, provide a link to the license, and indicate if changes were made. You may do so in any reasonable manner, but not in any way that suggests the licensor endorses you or your use. NonCommercial — You may not use the material for commercial purposes. NoDerivatives - If you remix, transform, or build upon the material, you may not distribute the modified material. You are free to: Share - copy and redistribute the material in any medium or format.

https://creativecommons.org/licenses/by-nc-nd/4.0/legalcode

If you use the work, we ask that you reference the APRA website (www.future-agricultures.org/apra/) and send a copy of the work or a link to its use online to the following address for our archive: APRA, Future Agricultures Consortium, University of Sussex, Brighton BN1 9RE, UK (apra@ids.ac.uk)

\section{Cccreative}

All APRA Working Papers go through a review process before publication.

DO YOU HAVE COMMENTS ON THIS PAPER?

We would welcome your feedback on this working paper!

To provide brief comments, please follow this link to our short APRA Working Paper Feedback form: https://goo.gl/forms/1iVnXhhrlGesfR9

Agricultural Policy Research in Africa (APRA) is a programme of the Future Agricultures Consortium (FAC) which is

generating new evidence and policy-relevant insights on more inclusive pathways to agricultural commercialisation in sub-Saharan Africa. APRA is funded with UK aid from the UK Foreign, Commonwealth \&

Development Office (FCDO) and will run from 2016-2022.

The APRA Directorate is based at the Institute of Development Studies (IDS), UK (www.ids.ac.uk), with regional hubs at the Centre for African

Bio-Entrepreneurship (CABE), Kenya, the Institute for Poverty, Land and Agrarian Studies (PLAAS), South Africa, and the University of Ghana, Legon. It

builds on more than a decade of research and policy engagement work by the Future Agricultures Consortium (www.future-agricultures.org) and involves more than 100 researchers and communications professionals in Africa, UK, Sweden and USA. 